\title{
INCIDENCE OF CLOSTRIDIUM PERFRINGENS IN SOME MEAT PRODUCTS WITH ENTEROTOXIC GENES DETECTION
}

\author{
ENGY F. ELBAHY ${ }^{1 *}$; WALAA M. ELKASSAS ${ }^{1}$; HASSEN M.A. ${ }^{2}$ and ADEL M. ELGAMAL ${ }^{3}$ \\ ${ }^{1}$ Department of Food Hygiene, Animal Health Research Institute, Kafrelsheikh Branch, Egypt. \\ ${ }^{2}$ Department of Food Hygiene, Faculty of Vetrinary Medicine, Benha University. \\ ${ }^{3}$ Department of Bacteriology, Animal Health Research Institute, Kafrelsheikh Branch, Egypt.
}

Received: 20 March 2016; Accepted: 5 April 2016

\begin{abstract}
The aim of the present study was to determine the presence of Clostridium perfringens, including toxic genes in some meat products. A total of 80 samples of minced meat, beef burger, sausage and canned beef luncheon ( 20 of each) were collected from different supermarkets in Kafrelsheikh city. C.perfringes was isolated with incidence of 15, 15, 20 and 30\%, respectively. Mean values of C.perfringes were $6.33 \times 10^{2}, 1.25 \times 10^{3}, 2.09 \times 10^{3}$ and $4.98 \times 10^{3} \mathrm{cfu} / \mathrm{g}$, respectively. The tested meat product samples confirmed the presence of positive C.perfringes for toxic genes as cpa, cpb, etx, iap and cpe. The obtained results revealed that 16 positive C.perfringens isolates were classified into 5(31.25\%) isolates were C.perfringens type A; 3(18.75\%) C.perfringens type B; 2 (12.5\%) C.perfringens type D; 1 (6.25\%) C.perfringens type E, 5 (31.25\%) were nontoxigenic C.perfringens and C.perfringens type $\mathrm{C}$ not detected in any of meat product samples. The result revealed that type A was the most predominant type. The percentage of toxigenic and non-toxigenic strains was $68.75 \%$ and $31.25 \%$. The public health importance of the isolated organism was discussed.
\end{abstract}

Key words: Clostridium perfringens, Enterotoxin gene, meat products, PCR.

\section{INTRODUCTION}

The microbiological quality and safety of commercially processed meat is major area of concern for producers, consumers and public health officials worldwide (Okolocha and Ellerbroek, 2005). Products excessively contaminated with microorganisms are undesirable from the stand point of public health, storage, quality and general aesthetics (Mead, 1989). Processed meat products constitute a good media for bacterial growth and multiplication, depending on many factors such as $\mathrm{pH}$, temperature biosafety measures and personal hygiene, which may lead to food intoxication and affect on the public health (FAO/WHO, 1983).

The quality of meat product depends on the quality of the used meat, additives, sanitary condition of the equipments and the processing procedures (Teufel et al., 1982).

Corresponding author: Dr. ENGY F. ELBAHY

E-mail address: engy.elbahy@yahoo.com

Present address: Department of Food Hygiene, Animal Health Research Institute, Kafrelsheikh Branch, Egypt.
Anaerobic bacteria constitute an important group of microorganisms which are responsible for many public health hazards as well as spoilage due to lack of oxygen. Clostridia are the most anaerobic organisms which contaminate food, due to production of their resistant spores (Barnes, 1985).

C.perfringens is Gram-positive, spore forming, rodshaped anaerobic bacteria and more widely spread than other pathogenic bacteria, its principal habitats are in the soil and the intestinal contents of man and animals (Songer, 2010). As well as, it has a great effect on the human health causing food poisoning, also C.perfringens causes a number of diseases for example necrotic enteritis in broiler chicken, enteritis in piglets, abomastitis and haemorrhagic enteritis in calves, and gas gangrene, food-poisoning, and gastrointestinal illness in humans (Golden et al., 2009). This pathogenicity is associated with lethal exteracellular toxins which have been defined as enzyme activity as collagenase, hyaluronidase and deoxyribonuclease (Norris and Pettipher, 1987). All C.perfringens food poisoning outbreaks have been caused by strains type (A) in which meat is an excellent medium for the bacterial growth. C.perfringens type A produces an enterotoxin (CPE) and can cause food poisoning outbreaks with diarrhea 
and severe abdominal pain related to consumption of food (Stevens and Bryant, 1997). Meat products may also be contaminated by different types of such microbes.

Food outbreaks caused by C.perfringens are usually those presenting with high counts in the meat products which have been exposed to insufficient cooking. Contamination of meat and meat products with C.perfringens may be through different sources, mainly internally from animal after slaughtering as postmortem invasion or externally from contaminated hands, skin of animals, soil, water and processing equipments (Satio, 1990).

So, the aim of the present study was to determine the incidence of C.perfringens in some meat products collected from different supermarkets in Kafrelsheikh city and screening the presence of enterotoxin genes.

\section{MATERIALS AND METHODS}

\section{Collection of samples:}

A total of 80 random samples of meat products represented by mined beef, beef burger, sausage and canned beef luncheon ( 20 of each) were collected under septic condition from different supermarkets in Kafrelsheikh city. The collected samples were transferred to the laboratory with minimum of delay and subjected to the bacteriological examination.

\section{Isolation and Identification of $\boldsymbol{C}$. perfringens:}

The technique recommended by Koneman et al. (1992) and Collee et al. (1996) was applied to detect C. perfringens in such examined samples. Accurately, 25 grams of each sample were diluted in $225 \mathrm{ml}$ of sterile $0.1 \%$ peptone water and homogenized for 2 minutes. Thus, $1 \mathrm{ml}$ of each homogenized food suspension was added to each of two tubes containing $10 \mathrm{ml}$ of sterile cooked meat broth (CMB). One of the two inoculated tubes was heat shocked at $72^{\circ} \mathrm{C}$ for 20 minutes before anaerobic incubation at $37^{\circ} \mathrm{C}$ for 24 hours to enrich for $C$. perfringens spores. The other tube was directly incubated anaerobically at $37^{\circ} \mathrm{C}$ for 24 hours for $C$. perfringens vegetative. However, the positive tube was streaked onto one plate of nutrient agar containing $10 \%$ sheep blood and $40 \mathrm{ug} / \mathrm{ml}$ neomycin and incubated for 24 hours at $37^{\circ} \mathrm{C}$ in an anaerobic jar. The suspected colonies were picked up and subcultured for further identification (morphologically and biochemically).

\section{Total anaerobic count of C.perfringens in meat products:}

It was carried out according the technique adapted by Cruickshank et al. (1975) and APHA (2001). The selective media plates of C.perfringens (TSC Agar, Trypton Sulphate Cycloserine) were streaked with 0.1 $\mathrm{ml}$ of the first and second dilution prepared from the collected samples diluted in sterile pepton water, incubated anaerobically at $37^{\circ} \mathrm{C}$ for $18-24 \mathrm{hrs}$ in the Gas Pack anaerobic jar and the average counts calculated.

\section{Detection of C.perfringens genes by multiplex PCR: \\ 4.1. Primer sequences of $C$. perfringens used for PCR system:}

Application of PCR for identification and characterization of cpa (400 bp), cpb (196 bp), etx (655 bp), iap (446 bp) and cpe (233 bp) virulent genes for characterization of Clostridium perfringens was performed essentially by using primers (Pharmacia Biotech) as shown in the following Table 1:

\begin{tabular}{|c|c|c|c|c|}
\hline Primer & Target gene & Oligonucleotide sequence $\left(5^{\prime} \rightarrow 3^{\prime}\right)$ & $\begin{array}{l}\text { Product } \\
\text { size (bp) }\end{array}$ & Reference \\
\hline $\mathrm{CPA}(\mathrm{F})$ & \multirow[b]{2}{*}{ cpa } & 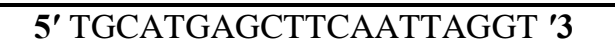 & \multirow[b]{2}{*}{400} & \multirow{11}{*}{$\begin{array}{c}\text { Heikinheimo and } \\
\text { Korkeala (2005) }\end{array}$} \\
\hline CPA (R) & & 5' TTAGTTTTGCAACCTGCTGT '3 & & \\
\hline $\mathrm{CPB}(\mathrm{F})$ & \multirow[b]{2}{*}{$\mathrm{cpb}$} & 5' GCGAATATGCTGAATCATCTA '3 & \multirow[b]{2}{*}{196} & \\
\hline $\mathrm{CPB}(\mathrm{R})$ & & 5' GCAGGAACATTAGTATATCTTC '3 & & \\
\hline $\operatorname{ETX}(\mathrm{F})$ & \multirow{3}{*}{ etx } & 5' GCGGTGATATCCATCTATTC '3 & \multirow{3}{*}{655} & \\
\hline & & & & \\
\hline$\overline{E T X}(\mathrm{R})$ & & 5' CCACTTACTTGTCCTACTAAC '3 & & \\
\hline IA $(F)$ & \multirow{2}{*}{ iap } & $\mathbf{5}^{\prime}$ ACTACTCTCAGACAAGACAG '3 & \multirow[b]{2}{*}{446} & \\
\hline IA (R) & & 5' CTTТССТТСТАТТАСТАТАCG '3 & & \\
\hline $\mathrm{CPE}(\mathrm{F})$ & \multirow[b]{2}{*}{ cpe } & 5' GGAGATGGTTGGATATTAGG '3 & \multirow[b]{2}{*}{233} & \\
\hline $\mathrm{CPE}(\mathrm{R})$ & & 5'GGACCAGCAGTTGTAGATA'3 & & \\
\hline
\end{tabular}




\subsection{DNA extraction (Shah et al., 2009):}

All strains were streaked on blood agar plates and incubated under anaerobic conditions at $37^{\circ} \mathrm{C}$ for 20 22 hours. After incubation, one or two typical colonies were picked and suspended in $100 \mu \mathrm{l}$ of distilled water. The tubes containing the suspensions were heated to $99^{\circ} \mathrm{C}$ for 10 minutes and centrifuged for $5 \mathrm{~min}$ at $10000 \mathrm{rpm}$. All bacterial DNA was stored at $-70^{\circ} \mathrm{C}$ prior to use. A total volume of $10 \mu \mathrm{l}$ was used as a template in the PCR.

\subsection{Amplification reaction of $C$. perfringens} (Meer and Songer, 1997):

The amplification was performed on a Thermal Cycler (Master cycler, Eppendorf, Hamburg, Germany). The multiplex PCR reaction mixture contained $50 \mathrm{ng} C$. perfringens template DNA, 62.5 pmol each cpa primer, 40 pmol each cpb primer, 55 pmol each etx primer, $70 \mathrm{pmol}$ each iap primer and 45 pmol each cpe primer, dNTPs to a final concentration of $0.1 \mathrm{mM}$ PCR buffer $(50 \mathrm{mM} \mathrm{KCl}, 10$
$\mathrm{mM}$ Tris- $\mathrm{HCl}, \mathrm{pH} 8.3,2 \mathrm{mM} \mathrm{Mgcl}_{2}$ ), 0.1 Triton X100, 2 units of Taq DNA polymerase and sterile $\mathrm{dH}_{2} \mathrm{O}$. Accordingly, the DNA was initially denaturated at $95^{\circ} \mathrm{C}$ for 2 min and amplified for 35 cycles $\left(1 \mathrm{~min}\right.$ at $94^{\circ} \mathrm{C}, 1 \mathrm{~min}$ at $55^{\circ} \mathrm{C}, 1 \mathrm{~min}$ at $72^{\circ} \mathrm{C}$ for denaturation, annealing and extension phases, respectively) and followed by an additional period of extension for $10 \mathrm{~min}$ at $72^{\circ} \mathrm{C}$. Amplified PCR products were separated by $2 \%$ of agarose gel electrophoresis (Applichem, Germany, GmbH) with $0.5 \mu \mathrm{g}$ ethidium bromide/ $\mathrm{ml}$. Thus, $20 \mu \mathrm{l}$ PCR products were subjected to electrophoresis for 45-60 min at 80 volts. Finally, the amplified products were visualized on UV transilluminator. A 100 bp plus DNA Ladder (Qiagen, Germany, GmbH) was used to determine the fragment sizes.

\section{Statistical analysis:}

The obtained results were statistically evaluated by using analysis of variance according to Feldmen et al. (2003).

\section{RESULTS}

Table (2): Incidence and statistical analytical results of C.perfringens cfu/g in the examined meat products $(n=20$ each):

\begin{tabular}{|c|c|c|c|c|c|}
\hline \multirow[b]{2}{*}{ Meat Products } & \multicolumn{2}{|c|}{ +ve samples } & \multirow[b]{2}{*}{ Min } & \multirow[b]{2}{*}{ Max } & \multirow[b]{2}{*}{ Mean \pm S.E $\mathbf{E}^{*}$} \\
\hline & No. & $\%$ & & & \\
\hline Minced meat & 3 & 15 & $1.0 \times 10^{2}$ & $1.2 \times 10^{3}$ & $6.33 \times 10^{2} \pm 1.47 \times 10^{2}$ \\
\hline Beef burger & 3 & 15 & $1.0 \times 10^{2}$ & $2.9 \times 10^{3}$ & $1.25 \times 10^{3} \pm 0.29 \times 10^{3}$ \\
\hline Sausage & 4 & 20 & $2.0 \times 10^{2}$ & $6.5 \times 10^{3}$ & $2.09 \times 10^{3} \pm 0.53 \times 10^{3}$ \\
\hline nned beef luncheon & 6 & 30 & $5.0 \times 10^{2}$ & $1.1 \times 10^{4}$ & $4.98 \times 10^{3} \pm 1.06 \times 10^{3}$ \\
\hline
\end{tabular}

*High significant differences between meat products $(\mathrm{P}>0.01)$

Table 3: Distribution of the toxin genes and types of C.perfringens isolated from meat products:

\begin{tabular}{|c|c|c|c|c|c|c|}
\hline \multirow[b]{2}{*}{ C. perfringens type } & \multirow[b]{2}{*}{$\begin{array}{c}\text { Positive } \\
\text { genes }\end{array}$} & \multicolumn{4}{|c|}{ Meat products } & \multirow[b]{2}{*}{ Total } \\
\hline & & $\begin{array}{c}\text { Minced } \\
\text { meat }\end{array}$ & $\begin{array}{c}\text { Beef } \\
\text { burger }\end{array}$ & Sausage & $\begin{array}{c}\text { Canned } \\
\text { beef } \\
\text { luncheon }\end{array}$ & \\
\hline $\mathbf{A}$ & сра & 1 & 1 & 1 & 2 & 5 \\
\hline B & cpa, cpb, etx & - & 1 & 1 & 1 & 3 \\
\hline $\mathbf{C}$ & сpa, cpb & - & - & - & - & - \\
\hline D & cpa, etx & - & - & 1 & 1 & 2 \\
\hline $\mathbf{E}$ & cpa, iap & - & - & - & 1 & 1 \\
\hline Non toxigenic & Negative & 2 & 1 & 1 & 1 & 5 \\
\hline Total & & 3 & 3 & 4 & 6 & 16 \\
\hline
\end{tabular}




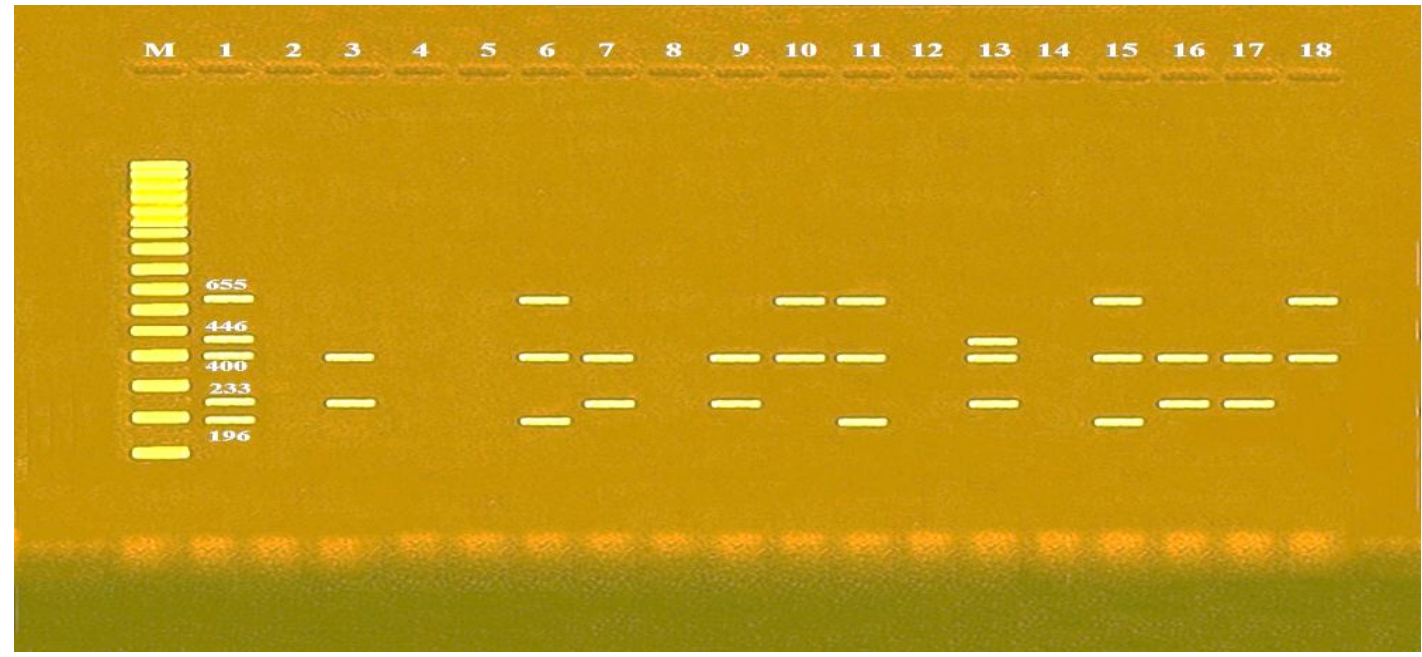

Figure (1): Agarose gel electrophoresis of multiplex PCR of cpa (400 bp), cpb (196 bp), etx (655 bp), iap (446) and cpe (233 bp) virulent genes for characterization of Clostridium perfringens.

Lane M: 100 bp ladder as molecular size DNA marker.

Lane 1: Control positive $C$. perfringens for cpa, cpb, etx, iap and cpe genes.

Lane 2: Control negative.

Lanes 3, 7, 9, 16 \& 17: Positive $C$. perfringens strains for cpa and cpe genes.

Lanes 6, 11 \& 15: Positive $C$. perfringens strains for cpa, cpb and etx genes.

Lanes 10 \& 18: Positive $C$. perfringens strains for cpa and etx genes.

Lanes 13: Positive $C$. perfringens strain for cpa, iap and cpe genes.

Lanes 4, 5, 8, 12 \&14: Negative $C$.perfringens strains cpa, cpb, etx, iap and cpe genes.

\section{DISCUSSION}

C.perfringens produce at least 17 toxins, including the C.perfringens enterotoxin (CPE) (Johansson et al., 2006) which is known to cause human food poisoning. C.perfringens intoxication can be due to ingestion of food containing an enterotoxigenic strain in a concentration $\geq 10^{5} \mathrm{cfu} / \mathrm{g}$ (Stagnitta et al., 2002). In vivo, enterotoxin production is associated to sporulation in the intestine (Dela et al., 2006), while an adequate culture medium is needed for in vitro production (Stagnitta et al., 2002). Vegetative cells that reach the intestine and undergo sporulation produce $\mathrm{CPE}$, which in turn is responsible for clinical symptoms. This toxin-infection is characterized by nausea, diarrhea, abdominal pain and gases, 6 to 12 hrs after intake of contaminated food. Recovery is fast, usually within $12 \mathrm{hrs}$ (Miyamoto et al., 2004). There is a correlation between CPE synthesis and spore formation, and this is the basis for enterotoxigenic and non-enterotoxigenic strain differentiation (Hathway, 1990).

C.perfringens has been classified to five toxotypes (A, B, C, D and E) based on production of four main toxins ( $\alpha$ Alpha, $\beta$ Beta, $\varepsilon$ Epsilon and 1 Iota toxins) (Johansson et al., 2006). This bacterium also produces ten other toxins such as CPE, beta2 toxins, and theta toxin (Effat et al., 2007).

Data shown in Table (2) revealed that C.perfringens was isolated from minced meat, beef burger, sausage and canned beef luncheon by percentage of $15 \%$, $15 \%, 20 \%$ and $30 \%$, respectively. Meanwhile, the mean values of C.perfringens counts were $6.33 \times 10^{2} \pm 1.47 \times 10^{2}, \quad 1.25 \times 10^{3} \pm 0.29 \times 10^{3}, \quad 2.09 \times 10^{3} \pm$ $0.53 \times 10^{3}$, and $4.98 \times 10^{3} \pm 1.06 \times 10^{3} \mathrm{cfu} / \mathrm{g}$, respectively and there is high significance differences $(\mathrm{P}>0.01)$ between C.perfringens counts in the examined meat products. The results of incidence were lower than results of Sharma et al. (1993); El-Lawendy (1996); Torky (2004); Elham and Nahla (2011), while nearly agreement with Wen and McClane (2004). The results of counts were lower than Yossef (1984); Hassan (2001) and Eleiwa (2003). Higher results in canned beef luncheon due to unhygienic excessive handling, additives and spices, contamination during processing and preservation (Miki, 2008).

It is obvious from Table (3) and figure (1) that 16 positive C.perfringens isolates were classified into $5(31.25 \%)$ isolates were C.perfringens type A; $3(18.75 \%) \quad$ C.perfringens type $\mathrm{B} ; 2$ (12.5\%) C.perfringens type D; 1 (6.25\%) C.perfringens type E, $5(31.25 \%)$ were non-toxigenic C.perfringens and C.perfringens type $\mathrm{C}$ not detected in any of meat product samples. The result revealed that type A was the most predominant type. The percentage of toxigenic and non-toxigenic strains was $68.75 \%$ and $31.25 \%$.

All type A strains produce $\alpha$ toxin, type B produce $\alpha$, $\beta$ and $\varepsilon$ toxins, type $C$ produce $\alpha$ and $\beta$ toxins, type $D$ produce $\alpha$ and $\varepsilon$ toxins, and type E produce $\alpha$ and $\mathrm{l}$ 
toxins (Layana et al., 2006). C.perfringens type B and $\mathrm{E}$ are recognized as frank pathogens for demostic animals and human, while type A are commensals in the intestinal tract of vertebrates, and the ability of higher expression of $\alpha$ toxin decides about lethal properties of these strains (Songer, 1996).

The pathogenicity of the organism is associated with several toxins which are also used for toxin typing of the bacteria, within them all strains of the bacterium produce $\alpha$ toxin encoded by (cpa gene). The other major lethal toxins produced by the organism are $\beta$ (cpb gene), $\varepsilon$ (etx gene) and 1 (iap gene) that are closely related with the virulence of the bacteria (Titball et al., 1999). In addition to these major lethal toxins, some strains, with a ratio of 0 to $5 \%$ have a capability of producing C.perfringens enterotoxin encoded by cpe gene that is the main cause of common C.perfringens type A food poisoning (Juneja et al., 2010). Strains type A carry the cpe gene in 5$8 \%$ of the global population (Miyamoto et al., 2004). $\mathrm{C}$ and D strains can also carry cpe gene and produce CPE (Czeczulin et al., 1996).

CPE induces clinical symptoms in vivo within 15-30 min of delivery of purified toxin (Smith, 1979). In man, symptoms develop when $>5 \times 10^{8}$ viable enterotoxigenic vegetative cells of C.perfringens reach the digestive system (Hatheway, 1990). The expression of cpe mRNA and CPE protein synthesis was strongly blocked in cells in the vegetative stage of growth, increasing up to 1500 times after starting the sporulation process (Melville et al., 1994). The classical approach of C.perfringes food poisoning involves the detection of $>10^{6}$ bacterial cells $/ g$ in fecal samples or serological detection of CPE after inducing sporulation of an isolate, or both (Smith, 1979). Characterization of enterotoxigenic C.perfringens isolates can be difficult as the ability to sporulate in vitro can vary with different media (Van Damme-Jongston et al., 1990). Moreover, CPE synthesis can occure in nonsporulating culture of C.perfringens (Petit et al., 1999).

Food poisoning caused by $C$. perfringens may occur when meat cooked and held without maintaining adequate heating before serving. In such cases the spores of some strains are resistant to temperature even at $100^{\circ} \mathrm{C}$ for more than $1 \mathrm{hr}$, their presence in food may be unavoidable and the oxygen level may be sufficiently reduced during cooking to permit growth of clostridia spores that survive cooking may germinate and grow rapidly in food that inadequately refrigerated after cooking (Asha et al., 2006). C.perfringens may be present in vegetables, spices and sea-sonings that were used as additives (Rodriguez et al., 2002).

C.perfringens is responsible for two different foodborne diseases, Type $\mathrm{A}$ and $\mathrm{C}$, and gas gangrene in humans as well as necrotic enteritis and enterotoxemia in poultry (Immerseel et al., 2004).

\section{CONCLUSION}

This study showed that the isolation rate of C.perfringens was high in meat products which play an important role in food poisoning. The anaerobic counts of the examined samples were not enough to induce food poisoning in human, since millions of viable C.perfringes are required to induce food poisoning in human $\left(10^{6}\right.$ microorganisms $\left./ g\right)$. So, careful inspection of raw materials, production lines and storing conditions should be intensified to eliminate serious contamination and produce safe and high quality products as well as ensuring compliance with legislation. Also, the use of PCR proved that it is rapid accurate test for detection of pathogenic food poisoning bacteria.

\section{REFERENCES}

APHA (American Public Heath Association) (2001): Compendium of methods for the microbiological examination of foods. $4^{\text {th }} \mathrm{Ed}$., Washington, DC.

Asha, N.J.; Tompkins, D. and Wilcox, M.H. (2006): Comparative analysis of prevalence, risk factors, and molecular epidemiology of antibiotic- associated diarrhea due to Clostridium difficile, Clostridium perfringens, and Stapylococcus aureus. J. Clin. Microbiol., 44: 2785-2791.

Barnes, E.M. (1985): Isolation methods for anaerobes in foods. International Journal of Food Microbiol., 33:77-82.

Collee, J.G.; Fraser, A.; Marmion, B. and Simmons, A. (1996): Practical Medical Microbiology. 14 Ed., Churchill Living Stone, New York, USA.

Cruickshank, R.; Duguid, I.P.; Marmion, B. and Swain, R.H. (1975): Medical microbiology. $12^{\text {th }}$ Ed., Livingstone, Iowa, New York.

Czeczulin, J.R.; Collie, R.E. and McClane, B.A. (1996): Regulated experession of Clostridium perfringens enterotoxin in naturally cpenegative type $\mathrm{A}, \mathrm{B}$, and $\mathrm{C}$ isolates of C.perfringens. Infect. Immun., 64(8): 3301-9.

Dela, W.P.; Gozum, M.M.; Lineberry, S.F.; Stassen, S.D.; Daurghtry, M. and Stassen, N.A. (2006): Rapid detection of enterotoxigenic Clostridium perfringens by real time fluorescence resonance energy transfer PCR. J. Food Prot., 69(6): 1347-53

Effat, M.M.; Abdallah, Y.A.; Soheir, M.F. and Rady, R.M.M. (2007): Characterization of C.perfringens field isolates, implicated in necrotic enteritis outbreaks on private broiler farms in Cairo by multiplex PCR. African Journal of Microbiology, 29-32. 
Eleiwa, N.Z. (2003): Effect of chemical preservatives on food poisoning bacteria in some locally manufactured meat products. Ph. D. Thesis, Vet. Medical Zagazig Univ. Benha Branch.

Elham, I. Atwa and Nahla A. Abou El-Roos (2011): Incidence of C.perfringens in meat products at some Egyptian Governorates. International J. of Microbiol. Research. 2(3): 196-203.

El-Lawendy, T.M.H. (1996): Occurrence of C.perfringens in locally produced meat products. M.V.Sc. Thesis (Food hygiene and control) Zagazig University, Benha Branch.

FAO/WHO (1983): WHO surveillance programme for control of food borne infection and intoxication in Europe. Inst. Veterinary Medical $2^{\text {nd }}$ report. Berlin.

Feldmen, D.; Hoffman, R. and Simpson, J. (2003): The solution for data analysis and presentation graphics. $2^{\text {nd }}$ ed. Abacus Lancripts, Inc. Barkeley, C.A. USA.

Golden, N.J.; Crouch, E.A.; Latimer, H.; Kadry, A.R. and Kause, J. (2009): Risk assessment for Clostridum perfringens in ready-to-eat and partially cooked meat and poultry products. J. Food Prot., 72(7): 1376-1384.

Hassan, H.F.M. (2001): Study on Gram positive bacteria in meat products. $\mathrm{Ph}$. D. Thesis, Vet. Medical Beni-Suef. Univ.

Hathway, C.L. (1990): Toxigenic Clostridia. Clin. Microbiol. Rev., 3:66-98.

Heikinheimo, A. and Korkeala, H. (2005): Multiplex PCR assay for toxinotyping Clostridium perfringens isolates obtained from Finnish broiler chickens. Letters in Appl. Microbiol., 40: 407-411.

Immerseel, F.V.; De Buck, J.; Pasmans, F.; Huyghebaert, G.; Haesebrouk, F. and Ducatelle, R. (2004): Clostridium perfringens in poultry: an emerging threat for animal and public health. Avian Pathol., 33: 537-549.

Johansson, A.; Aspan, A.; Bagge, E.; Baverud, V.; Engstrom, B.E. and Johanssön, K.E. (2006): Genetic diversity of Clostridium perfringens type A isolates from animals, food poisoning outbreaks and sludge. BMC Microbiol., 31(6): 47.

Juneja, V.K.; Novak, J.S. and Labbe, R.L. (2010): Clostridium perfringens. 53-70.In: Juneja VK, Sofos JN (Ed). Pathogens and Toxins in Foods: Challenges and Intervention, ASM Press, Washington DC.

Koneman, K.; Allen, S.; Dowell, V. and Sommers, H. (1992): Color atlas and text book of diagnostic microbiology. $2^{\text {nd }}$ Ed., B. Lippicott Co., London, UK.

Layana, J.E.; Miyakawa, M.E.F. and Uzal, F.A. (2006): Evaluation of different fluids for detection of C.perfringens type D epsilon toxin in sheep with experimental enterotoxemia. Anaerobs, 12:204-206.
Mead, G.C. (1989): Hygienic problems and control of process contamination. In G.C. Mead, (Ed), processing of poultry: 183-221. London: Elsevier, Applied Science.

Meer, R.R. and Songer, J.G. (1997): Multiple polymerase chain reaction assay for genotyping Clostridium perfringens. J. Vet. Res., 58: 702-705.

Melville, S.B.; Labbe, $R$. and Sonenshein, A.L. (1994): Expression from the Clostridium perfringens cpe promotor in Closridium perfringens and Bacillus subtilis. Infect. Immun., 62: 5550-5558.

Miki, Y.; Miyamoto, K.; Kaneko-Hirano, I.; Fujiuch, $K$. and Skimoto, S. (2008): Prevalence and characterization of enterotoxin gene-carrying C.perfringens isolates from retail meat products in Japan. Applied Environ. Microbiol., 74: 5366-5372.

Miyamoto, K.; Wen, Q. and McClane, B.A. (2004): PCR genotyping assay that distinguishes between isolates of Clostridium perfringens type A carrying a chromosomal enterotoxin gene (cpe) locus, a plasmid cpe locus with an IS1470-like sequence, or a plasmid cpe locus with an IS1151 sequence. J. Clin. Microbiol., 42(4): 1552-8.

Norris, J.R. and Pettipher, G.L. (1987): Essays in Agricultural and Food Microbiology.

Okolocha, E.C. and Ellerbroek, L. (2005): The influence of acid and alkaline treatment on pathogens and the shelf life of poultry meat. Food Control, 16:217-225.

Petit, L.; Gibert, M. and Popoff, M.R. (1999): C.perfringens toxinotype and genoyype. Trends Micrbiol., 7:104-110.

Rodriguez, E.; Gamboa Mdel, M. and Vargas, $P$. (2002): Clostridium perfringens in raw and cooked meats and its relation with the environment in Costa Rica. Arch Latinoam Nutr., 52(2): 155-9.

Satio, M. (1990): Production of enterotoxin by C.perfringens drived from humans, animals foods and the natural environemet in Japan. Journal Food Prot., 53:115-118.

Shah, D.; Shringi, S.; Besser, T. and Call, D. (2009): Molecular detection of foodborne pathogens. Boca Raton: CRC Press, In Liu, D. (Ed). Taylor \& Francis group, Florida, USA, Pp. 369-389.

Sharma, N.K.; Saini, S.S.; Gill, J.P.S. and Kwatra, M.S. (1993): Occurrence of C.perfringens in uncooked cock tail sausage at retail level and its public health significance. Indian Journal of Animal Sci., 63:112-114.

Smith, L.D.S. (1979): Virulence factors of C.perfringens. Rev. Infect. Dis., 1:254-262.

Songer, J.G. (1996): Clostrdial enteric diseases of domestic animals. Clin. Microbiol. Rev., 9:216-234. 
Songer, J.G. (2010): Clostridial as agents of zoonotic disease. Vet. Microbiol., 140:399-404.

Stagnitta, P.V.; Miccalizzi, B. and de Guzmán, A.M.S. (2002): Prevalence of enterotoxigenic Clostridium perfringens in meats in San Luis, Argentina. Anaerobe., 8(5):253-8.

Stevens, D.L. and Bryant, A.E. (1997): Pathogenesis of Clostridium perfringens infection: mechanisms and mediators of shock. Clin. Infect. Dis., 25(2):160-164.

Teufel, P.; Goetz, G. and Grossklaus, D. (1982): Effect of factory hygiene and raw material on the microbiological status of minced meat. Fleischwirtsch, 62:1404.

Titball, R.W.; Naylor, C.E. and Basak, A.K. (1999): The Clostridium perfringens $\alpha$-toxin. Anaerobe, 5:51-64.
Torky, A.A.Sh.A. (2004): Trials for inhibition of some food poisoning microorganisms in meat products. Ph. D. V. Thesis Fac. Vet. Med. (Cairo University).

Van Damme-Jongsten, M.; Rodhouse, J.; Gillbert, R.J. and Notermans, S. (1990): Synthetic DNA probes for detection of enterotoxigenic C.perfringens strains isolated from outbreaks of food poisoning. J. Clin. Microbiol., 28: 131133.

Wen, $Q$. and McClane, B.A. (2004): Detection of C.perfringens type A isolates in american retail foods. Applied Environment Microbiol., 70: 2685-2691.

Yossef, H. (1984): Incidence of C.perfringens in meat products in Assuit City. Assuit Veterinary Medical Journal, 12(23):145-147.

\section{مدى تواجد الكلوستريديا بيرفيرنجنسن في بعض منتجات اللحوم والكشف على الجينات المسببة للسموم

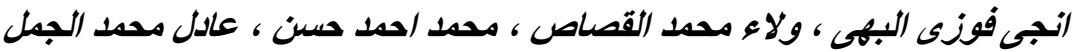

E-mail: engy.elbahy@yahoo.com Assiut University web-site: www.aun.edu.eg

الهدف من هذه الدراسة هو تحديد مدى تواجد الكلوستريديا بيرفيرنجنسن والجينات المسؤولة عن افراز السموم فى بعض منتجات

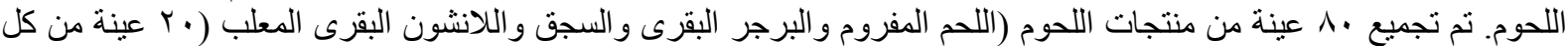

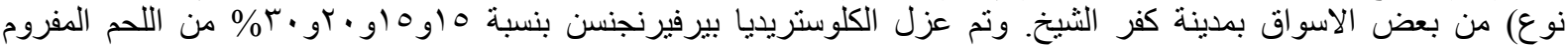

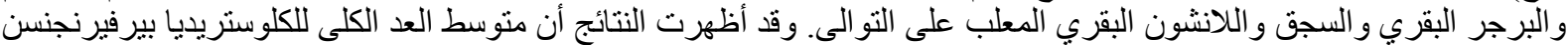

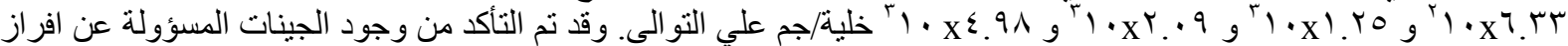

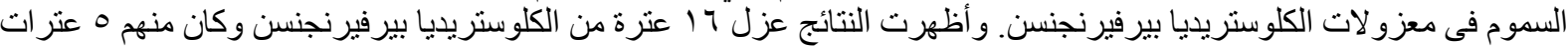

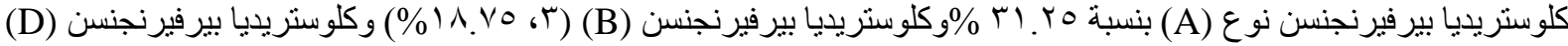

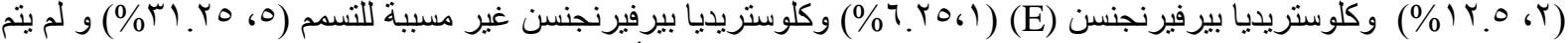

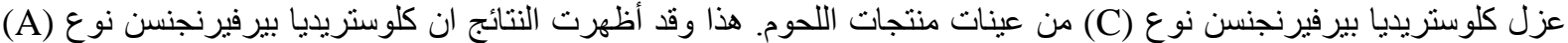

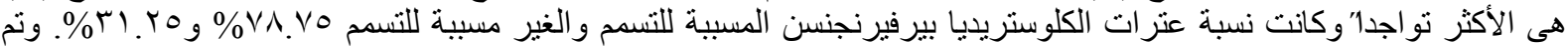

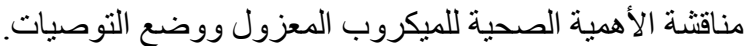

